International Journal of Instruction e-ISSN: 1308-1470 • www.e-iji.net

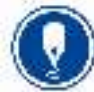

July $2021 \bullet$ Vol.14, No.3

p-ISSN: 1694-609X

pp. 501-518

Article submission code:

20200630133421

Received: 30/06/2020

Revision: 30/12/2020
OnlineFirst: 23/05/2021
Accepted: 25/01/2021

\title{
EFL Students' Perceptions of Online Distance Learning for Enhancing English Language Learning During Covid-19 Pandemic
}

\section{Wafa' A. Hazaymeh}

Asst. Prof., Al-Ain University, Al Ain, United Arab Emirates,

wafa.hazaymeh@aau.ac.ae

The study aimed to investigate participants' perceptions of online distance learning during Covid-19 Pandemic for empowering them to achieve ISTE standards within EFL classroom. 60 undergraduate students participated in this study through responding to a designed online survey based on ISTE standards. Data analysis indicated that the participants had a positive attitude of online distance learning which empowered them to develop high scores of creativity and innovation, communication and collaboration, research and information fluency, critical thinking, problem-solving, decision-making and digital citizenship. The results also showed that majority of respondents $(86.66 \%)$ acquired language proficiency successfully through online distance learning which indicated a flexible and suitable learning environment. However, the findings indicated few drawbacks of online distance learning due to technical problems and the lack of physical interactions. The results suggested that instructors should be aware of the effectiveness of digital technologies as instructional method for empowering their students to achieve ISTE standards within online EFL classroom.

Keywords: online distance learning, EFL students' perceptions, English language learning, learning, Covid-19 Pandemic

\section{INTRODUCTION}

Learning English as a universal language is a demand for all learners to cope with modern life. Educators and researchers have revealed that technology has the greatest role in raising learners' awareness, providing knowledge and facilitating learning the English language. E-learning can improve learners' linguistic skills, develop their ability in punctuation, grammar and spelling, creating an opportunity to enhance their performance in writing, listening, speaking and reading skills, as well, integrating technology in education plays an integral part in facilitating English language teaching and learning environment by digitalizing all content to be available on demand. In addition to the usefulness of technological devices as a tool for improving EFL learners' English language (Ahmadi \& Reza, 2018; Hasanand, 2017; Holtman, 2009; Lai \& Kritsonis, 2006; Milonm \& Abu-Ayfah, 2020; Pozzobon, 2008). Online distance learning or online learning are used interchangeably because they become a trend in this

Citation: Hazaymeh, W. A. (2021). EFL students' perceptions of online distance learning for enhancing English language learning during covid-19 pandemic. International Journal of Instruction, 14(3), 501-518. https://doi.org/10.29333/iji.2021.14329a 
era to solve learners' difficulties all over the world who may not show up at the educational institutions. It involves technology use and e-learning to provide learners with online education that help improving their communication skills and enriching their learning experiences. Hiltz and Turoff (2005) considered online or digital learning as a social process and a complete substitute for conventional distance learning. Kapla and Haenlein (2016) specified that through using the conventional distance learning, the academic material is planned and organized by educational institutions to be delivered to students who are separated by distance. Throughout history, the delivery of education primarily consisted of a classroom setting with an instructor delivering the required content to the students in a conventional method (Summers et al., 2005). However, the rapid development of technology has given birth to what is known as distance learning. Distance education methods have been developed through time using radios followed by televisions and then depending on the Internet connections (Bourne, 1998; Wang et al., 2013). Online learning exposed to a vast development, consequently universities have corresponded to this growth and started offering online courses to reach countless learners, remain accessible and make higher education more attainable to those who cannot seek their education through the conventional methods (Armstrong, 2011; Castle \& McGuire, 2010; Keengwe \& Kidd, 2010). Therefore, e-learning is considered as a motivational method for developing self-learning and language pedagogy for nowadays digital students. Blending technology with the conventional methods of language learning and teaching has been increasingly used to bridge the gap in most educational settings for enhancing the language learning and teaching process (Suppasetseree and Dennis, 2010). A plethora of researches has examined the application of technology in a classroom environment for supporting language learning and teaching. For instance, Shadiev and Yang (2020) defined technology as an "accomplishing a learning task or instructional goal using technical processes, methods or knowledge". Many studies concluded that using technology in the classroom for language learning and instruction is as effective as the traditional methods for supporting and improving learners' performance, interaction, feedback effect and motivation (Golonka et al (2014; Shadiev \& Huang, 2020). As a result, using digital innovative approaches to offer authentic learning experiences by providing multimedia lessons, interesting e-activities and interactive e-discussions can motivate learners to enhance language learning experiences.

Furthermore, the success of language learning development depends on real interaction between educators and their students. This interaction can be achieved by utilizing technological tools in the education system. Studies showed that applied technology was valuable in developing language skills, providing the appropriate feedback and improving the learning environment through realistic communication between students and their teachers. As well, students were happy to learn a language in the environments utilizing technological techniques. However, few researchers indicated that it is very challenging to use the distance education system to teach the English language because of the absence of the direct interaction between teachers and learners. Therefore, the solution could be distance learning through using technological tools that are depending 
on the direct interaction between educators and learners (Ghanizadeh et al, 2015; Memić-Fišić \& Bijedić 2017).

\section{Literature Review}

Related studies indicated that online distance learning is widely used in education, in general, and revealed an important role in English language learning, in particular. This importance comes from the benefits which affect educators and learners through facilitating their interactions, participation, collaborations, practising and acquiring knowledge. Similarly, some studies showed that in all societies, educators can make a giant progressive contribution. Making such a contribution is a challenge, and educators must willingly embrace new teaching and learning opportunities. Educators recognize that they must teach students using current and emerging technologies so that they provide students with the skills they will need. Besides, blending technology with education can provide unique, effective, and powerful opportunities for many different types of instruction and learning. (Moore et al, 2011; Shelly et al, 2013). Most researchers revealed that online learning motivated student to learn effectively. Zamari et al (2012) indicated that students were motivated to try online learning activities even if there was no assessment on these activities. However, they found that the majority of the students have difficulties with internet connection preventing them from going online to attend classes.

Gómez et al (2012) supposed that distance learning and online learning are synonyms as they follow the same instructional methods to deliver various instructional materials. In their study about students' perceptions of a web-based distance course, they also found that using technological tools such as chats, forums, e-mails and videos allow students to communicate, interact and provide feedback about the content of the course successfully. Similarly, students displayed positive attitudes of online learning as they acquired numerous benefits such as saving time, effort, and money. Besides, Al Zumor et al (2013) stated that using technological tools in teaching environment enrich English skills effectively, enhance students' confidence and cooperation for language learning. Hos et al (2016) displayed that most students had a positive attitude of online learning depending on multimedia in teaching because it has many advantages for developing their language skills, particularly listening, and their vocabularies. Rahmawati (2016) found that students' perceptions regarding using e-learning in English language skills ranging from extremely positive to an unwillingness to use it. It also revealed that elearning was flexible, provided innovative information and rich resources, increased cooperation among students and encouraged them to be more active and learn effectively. However, it showed some disadvantages of e-learning to be careful such as: reducing of social interaction and communication, shortage of digital resources and technological skills, slow connections, lack of instructors' feedback, increasing the opportunity of cheating and it cost a lot for using. Moreover, Erarslan and Topkaya (2017) found that EFL students had partially positive attitudes of online courses because they had awareness of the course content and aims; in addition to the knowledge they develop from e-learning platform. However, e-learning did not completely help them in terms of overall success in English at the preparatory class. 
A study conducted by Memić-Fišić and Bijedić (2017) revealed that students showed a positive attitude about the innovative design and structure of the teaching materials provided electronically. Cakrawati (2017) indicated that the majority of students considered online learning platforms in English teaching and learning as effective and satisfactory tools. The study also revealed that most of the students agreed about the effectiveness of the online learning platforms to develop English language skills, acquire new vocabularies and enhance their understanding of the lesson contents. Ahmadi and Reza, (2018) indicated that using the appropriate technology for language learning highly motivates learners to learn language skills effectively. It also can carry many advantages for educators and learners in solving their learning problems in a meaningful way and having a continuous interaction and connection to understand the course. Besides, they showed that digital teaching empowered learners to develop creativity, critical thinking skills, independent learning, building knowledge and promoting their collaboration. Altunay (2019) specified that students were pleased to study language skills via online distance learning because they admired its flexibility in saving time and place. However, they faced technical problems and an absence of some technological tools. The study also showed that students had difficulties in learning English language skills.

\section{The Benefits of Online Distance Learning}

Online distance learning is a flexible approach that allows students to study wherever they are aligned with other life commitments based on digital technology tools. Universities have offered this kind of learning in the 1990s in the form of printed course materials while students were attending a few conventional sessions, practising activities, doing assignments, discussing with peers, consulting instructors and doing examinations at the end of semesters (Basaza, et al, 2010). Due to technological development, online distance learning grows rapidly throughout the world to provide students, who are not able to gain traditional education, with innovative and intensive online distance courses which increase their responsibility to learn and work independently (Al-Fahad, 2009). McKnight et al (2016) introduced five roles of technology in developing learning environment: it improves teachers and learners access to latest e-resources, improves communication skills among teachers and learners, helps teachers to rearrange their time, expands learners' purposes for the future workplace and creates new roles for teachers and learners. Moreover, online distance learning may help students to be ready for the workplace after graduation. It may also enhance student-centred learning, improve learning outcomes, create dynamic learning environments that enable students to be independent, skilful and creative learners in using the modern curriculum.

\section{Digital Platforms: Moodle and Office 365}

Fauzan and Ngabut (2018) stated that teaching at the university level should support students to be critical thinkers and independent learners to develop English language proficiency effectively through using instructional technology such as flipped learning. Therefore, in most university educational settings, educators apply technology as a pedagogical tool to facilitate communication skills and the whole learning process 
among students and educators. Therefore, many technological platforms are used as a medium of communication skills. Moodle, for example, is considered one of the most operative Web-based tool to enhance English language learning. Feizabadi et al (2016) investigated the impact of English learning software Moodle and revealed that Moodle has an affirmative impact on improving language learning and has an effective change in the education system. They define Moodle as a kind of "free learning management system" or an open software with no cost for creating effectiveness and finding solutions for many educational system problems. Moodle software is a free platform for producing technology-based classes. It was created and designed according to constructivism school which believe that students can involve successfully in the learning process through interaction and communication with other students and their instructor. Moodle is the acronym for "Modular Object-Oriented Dynamic Learning Environment". It is an easy, dynamic and flexible online distance learning platform to support the collaborative learning environment and deliver courses fruitfully. Via Moodle, users can connect, interact and communicate effectively. They can also save information, share tasks and assignments quickly. Then, they can implement tests, upload and download materials easily. As well, through Moodle users can connect with the latest communication technologies such as wiki, forums and blogs directly. Besides, students can get immediate feedback about their quizzes, assignments, and other tasks.

Microsoft provided MS-Teams application as a tool for online distance learning and a centre for teamwork in Office 365 which is used to have interaction between educators and students for online classes. It is a communication and collaboration platform that includes team conversations, workplace chat, video meetings, file storage and application integration. Microsoft headquarters launched MS-Teams service worldwide in 2017 and in 19 languages. Since announcing MS-Teams, millions of active users have started using this innovative application which empowers individuals, teams, and organizations with wide-ranging and deepest toolkit for collaborations. It can be sorted in all technological devices to facilitate communication. As a digital workplace, it is constructed on four core facilities: chat for today's' teams, a hub for teamwork, customization options and security team trust (Warren,2020).

\section{1st Century Skills}

Several studies assured the importance of 21 st-century skills in the digital age (Himmelsbach, 2019; Kaur, 2019; Shelly et al, 2013). For instance, Shelly et al (2013) stated that 21 st Century Skills Partnership is a national organization that focuses on infusing technology skills in K-12 and higher education to support and improve teaching and learning through integrating skills into different academic subjects. She added that digital students can be hyper communicators who use multiple tools to communicate, multitaskers who do several things at once with ease and goal-oriented as they follow multiple goals at the same time. Besides, Kaur (2019) described digital education as a "revolutionary method of teaching" to deliver information remotely through multimedia tools provided to educators and students such as smart boards and LCD screens. A recent leading organization in education is the International Society for Technology in Education (ISTE) promotes the use of technology to support and improve the teaching 
and learning process. ISTE supports all areas of K-12 education, community colleges and universities, and teacher education organizations. ISTE has published the National Educational Technology Standards for students (NETS-S) in 1998. Then, in 2008, seven standards were provided for teachers to be: learners who improve their technological practices to develop students' learning; leaders who look for opportunities to provide the student with empowerment and success to develop teaching and learning; citizens who inspire students to positively participate in the digital world; collaborators who collaborate with colleagues and students to develop practice, discover and share resources, ideas, and solve problems; designers who design authentic, learner-driven activities and environments that identify learner variability; facilitators who facilitate learning with technology to support student achievement and analysts who understand and use data to drive their instruction and encourage students to achieve their learning goals (Smith, 2017).

The ISTE Standards were designed to reflect ideologies for improving online learning and professional development resources and empowering teachers and students to use technology in education effectively. The ISTE Standards for students have passed in three phases. The first phase was issued in 1998 focusing on helping the student to learn technology. The second phase was developed in 2007 concentrating on preparing students using technology to learn. ISTE also worked on the next generation and provided six standards to be a road map for students (ISTE -S) which focused on skills and expertise: "creativity and innovation; communication and collaboration; research and information fluency; critical thinking, problem-solving and decision-making; digital citizenship; and technology operations and concepts as clarified in figure1. The third phase was updated and designed in 2016 focusing on transformative learning with technology to prepare digital students to create authentic and digital learning through updating seven ISTE Standards for Students. These standards form a framework for teaching and learning in the digital age, helping digital students to be empowered learners and improving learning to be a student-driven process in anytime and anywhere. In the updated standards, students should be: "Empowered Learners, Digital Citizens, Knowledge Constructors, Innovative Designers, Computational Thinkers, Creative Communicators, and Global Collaborators as shown in Figure 2. These specific technology skills complement the key elements for 21st-century learning (International Society for Technology in Education, 2011; Shelly et al, 2013; Smith, 2017).

\section{Statement of the Problem}

Although students' perceptions regarding online learning have been emphasized in literature, but there are limited studies of online distance learning platforms used before the spread of the world-wide health crisis, COVID-19 Pandemic in 2020. It rises the sense of panic globally. Therefore, almost all the educational institutions have been closed and adopted distance learning for teaching online classes and creating an online environment through using digital pedagogy, technology and media (Kamenetz, 2020). Further, no any study has been attempted to investigate students' perceptions of online distance learning for achieving ISTE Standards within EFL classroom. Accordingly, this study was designed to answer the following questions: 
1. Does online distance learning empower participants to achieve ISTE Standards within EFL classroom effectively?

2. Does online distance learning develop participants" English language skills?

3. What are the drawbacks of online distance learning in teaching English classroom?

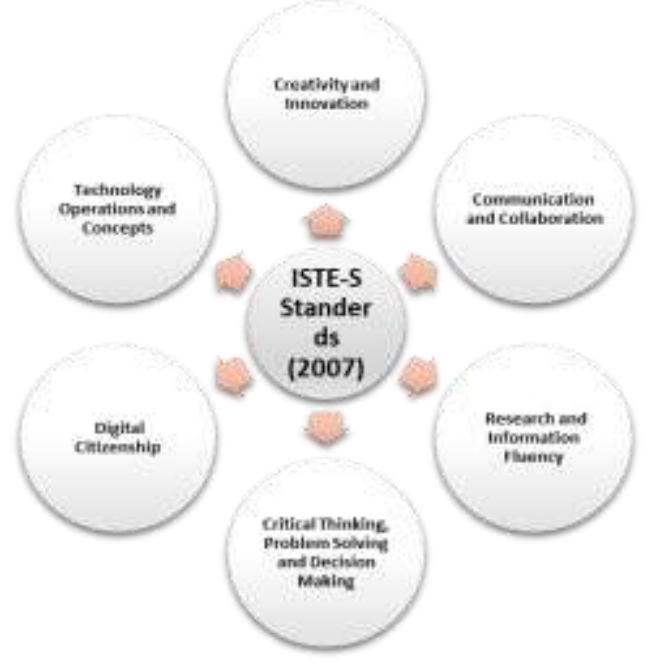

Figure 1

ISTE educational technology standards for students (ISTE-S, 2007)

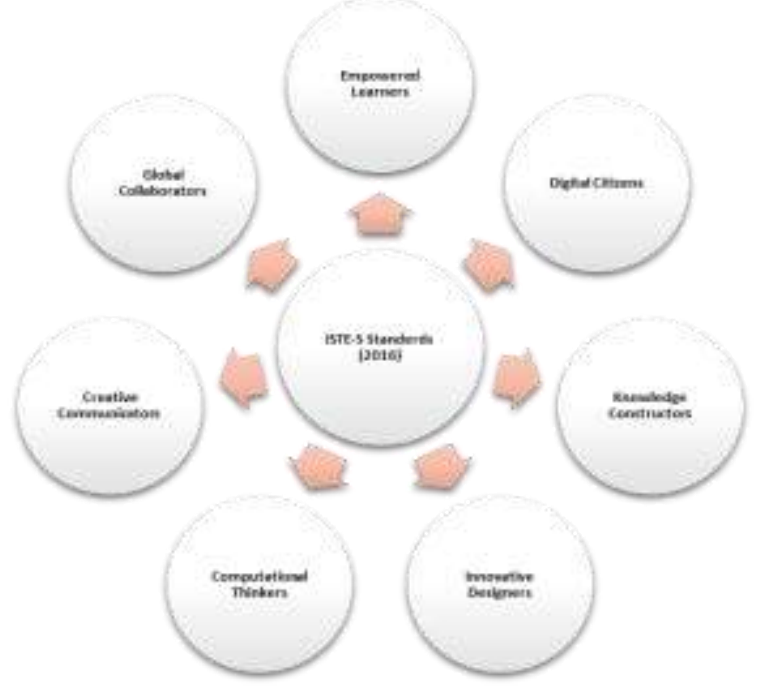

Figure 2

ISTE educational technology standards for students (ISTE-S, 2016)

International Journal of Instruction, July $2021 \bullet$ Vol.14, No.3 


\section{METHOD}

\section{Participants}

The participants of this study were 60 undergraduates EFL learners in their first year. They were between 18 and 20 years old registering English II course during the Second Semester of the academic 2020. This course is to apply active learning strategies to encourage students' communicating in English language orally or in writing. Another goal is to foster students' abilities to use current technological techniques to solve tasks and problems relevant to the English language four skills (listening, speaking, reading and writing) in a grammatical framework suitable to their level.

\section{The Instrument and Procedures}

The survey was designed according to International Standards Educational Technology Standards for Students (ISTE-S, 2007). The survey was pre-tested on 10 respondents and their views were considered to design the final version. The survey was divided into two sections including a cover letter. The first section composed of 24 close-ended statements adapted from the 6 basic standards (each of these standards has 4 statements) to measure the participants' perceptions of the usefulness of online distance learning for enhancing their English language skills. The second section was to collect information about the advantages and disadvantages of online distance learning on developing participants' English language skills. Participants were required to complete the survey which was a Likert-scale from $0-5$ with 0 for totally disagree and 5 for totally agree. The survey was added to the Moodle to collect data electronically. The respondents have to choose one option from a dropdown box. The researcher explained to them the purpose of the study and assured them about the confidentiality of their results.

First of all, in order to examine if online distance learning empowers participants to achieve ISTE Standards within EFL classroom effectively, the course content was delivered via digital platforms to improve their language proficiency through word recognition, reading, writing, listening and speaking skills. For instance, English language skills were delivered through videos, multimedia lessons, online tasks, selfreflection quizzes, worksheets, forums, bloggers, Google shared documents and flipped lessons. After practicing these activities, the participants provided with immediate feedback about their results with relevant comments to enhance their understanding and progress in language skills. For example, to improve participants' critical thinking, reading and speaking skills, they were asked to read several cases relating to real life situations, think critically to find solution and then engage in online discussions to come up with the correct clarification to these cases. As well, to develop participants' communication, collaboration, listening and speaking skills, they were asked to watch several videos, work in groups to answer relevant questions and then practice speaking through acting different roles.

Next, to raise the participants' innovation, creativity and writing ability, they were provided with several written topics as model examples. Then, they were asked to analyze and paraphrase them using their language. Later, they were asked to write a similar topic or a report after brainstorming it in a group discussion. Finally, the 
participants were asked to express their perceptions by responding to the survey if online distance learning empowers them to achieve ISTE Standards within EFL classroom effectively by responding to the survey. The respondents took nearly 10-15 minutes to complete and submit the responses. The collected data were statistically analyzed through SPSS.

\section{FINDINGS AND DISCUSSION}

Data was calculated and presented based on the participants' responses to the survey. Then it has been statistically analyzed through SPSS as reported in tables below. Table 1 showed the percentages and the number of participants' responses on each item.

Table 1

Scoring percentages of the participants' responses

\begin{tabular}{|c|c|c|c|c|c|c|}
\hline $\begin{array}{l}\text { ISTE-S } \\
\text { Standards }\end{array}$ & Statements & SD & $\mathrm{D}$ & $\mathrm{N}$ & $\mathrm{A}$ & SA \\
\hline \multirow{8}{*}{$\begin{array}{l}\text { I. Creativity and } \\
\text { Innovation }\end{array}$} & \multirow{2}{*}{$\begin{array}{l}\text { Using technology to generate } \\
\text { new ideas, products, or processes }\end{array}$} & 0 & 2 & 13 & 28 & 17 \\
\hline & & $0.00 \%$ & $3.33 \%$ & $21.67 \%$ & $46.67 \%$ & $28.33 \%$ \\
\hline & \multirow{2}{*}{$\begin{array}{l}\text { Using technology helps to create } \\
\text { original works as a means of } \\
\text { personal or group expression }\end{array}$} & 0 & 3 & 10 & 25 & 22 \\
\hline & & $0.00 \%$ & $5 \%$ & $16.66 \%$ & $41.67 \%$ & $36.67 \%$ \\
\hline & \multirow{2}{*}{$\begin{array}{l}\text { Using technology to practice } \\
\text { models and simulations to } \\
\text { explore complex systems and } \\
\text { issues }\end{array}$} & 0 & 5 & 10 & 30 & 15 \\
\hline & & $0.00 \%$ & $8.33 \%$ & $16.67 \%$ & $50 \%$ & $25 \%$ \\
\hline & \multirow{2}{*}{$\begin{array}{l}\text { Using technology to identify } \\
\text { trends and forecast possibilities }\end{array}$} & 0 & 5 & 18 & 25 & 12 \\
\hline & & $0.00 \%$ & $8.33 \%$ & $30 \%$ & $41.67 \%$ & $20 \%$ \\
\hline \multirow{8}{*}{$\begin{array}{l}\text { II. } \\
\text { Communication } \\
\text { and } \\
\text { Collaboration }\end{array}$} & \multirow[b]{2}{*}{$\begin{array}{l}\text { Using digital media to interact, } \\
\text { collaborate, and publish with } \\
\text { peers, experts, or others } \\
\text { employing a variety of digital } \\
\text { environments and media }\end{array}$} & 0 & 3 & 5 & 30 & 22 \\
\hline & & $0.00 \%$ & $5 \%$ & $8.33 \%$ & $50 \%$ & $36.67 \%$ \\
\hline & \multirow{2}{*}{$\begin{array}{l}\text { Using digital media to } \\
\text { communicate ideas effectively to } \\
\text { multiple audiences using a } \\
\text { variety of media and formats }\end{array}$} & 0 & 5 & 8 & 28 & 19 \\
\hline & & $0.00 \%$ & $8.33 \%$ & $13.33 \%$ & $46.67 \%$ & $31.67 \%$ \\
\hline & \multirow{2}{*}{$\begin{array}{l}\text { Using digital media to develop } \\
\text { cultural understanding and global } \\
\text { awareness by engaging with } \\
\text { learners of other cultures }\end{array}$} & 0 & 2 & 9 & 33 & 16 \\
\hline & & $0.00 \%$ & $3.33 \%$ & $15 \%$ & $55 \%$ & $26.67 \%$ \\
\hline & \multirow{2}{*}{$\begin{array}{l}\text { Using digital media to contribute } \\
\text { to project teams to produce } \\
\text { original works or solve problems }\end{array}$} & 0 & 8 & 11 & 27 & 14 \\
\hline & & $0.00 \%$ & $13.33 \%$ & $18.33 \%$ & $45 \%$ & $23.33 \%$ \\
\hline \multirow{6}{*}{$\begin{array}{l}\text { III. Research and } \\
\text { Information } \\
\text { Fluency }\end{array}$} & \multirow{2}{*}{$\begin{array}{l}\text { Applying digital tools to create } \\
\text { plan strategies to guide inquiry }\end{array}$} & 0 & 4 & 25 & 18 & 13 \\
\hline & & $0.00 \%$ & $6.66 \%$ & $41.67 \%$ & $30 \%$ & $21.67 \%$ \\
\hline & \multirow[b]{2}{*}{$\begin{array}{l}\text { Applying digital tools to locate, } \\
\text { organize, analyze, evaluate, } \\
\text { synthesize, and ethically use } \\
\text { information from a variety of } \\
\text { sources and media }\end{array}$} & 1 & 10 & 15 & 19 & 15 \\
\hline & & $1.66 \%$ & $16.67 \%$ & $25 \%$ & $31.67 \%$ & $25 \%$ \\
\hline & \multirow{2}{*}{$\begin{array}{l}\text { Applying digital tools to } \\
\text { evaluate, select information } \\
\text { sources and digital tools based on }\end{array}$} & 1 & 9 & 16 & 20 & 14 \\
\hline & & $1.67 \%$ & $15 \%$ & $26.67 \%$ & $33.33 \%$ & $23.33 \%$ \\
\hline
\end{tabular}




\begin{tabular}{|c|c|c|c|c|c|c|}
\hline & \multicolumn{6}{|l|}{$\begin{array}{l}\text { the appropriateness of specific } \\
\text { tasks }\end{array}$} \\
\hline & Applying digital tools to process & 0 & 11 & 14 & 22 & 13 \\
\hline & data and report results & $0.00 \%$ & $18.33 \%$ & $23.33 \%$ & $36.67 \%$ & $21.67 \%$ \\
\hline \multirow{8}{*}{$\begin{array}{l}\text { IV. Critical } \\
\text { Thinking, } \\
\text { Problem- } \\
\text { Solving, and } \\
\text { Decision- } \\
\text { Making }\end{array}$} & Using digital tools and resources & 2 & 5 & 8 & 34 & 11 \\
\hline & $\begin{array}{l}\text { to identify, define authentic } \\
\text { problems and significant } \\
\text { questions for investigation }\end{array}$ & $3.33 \%$ & $8.33 \%$ & $13.33 \%$ & $56.67 \%$ & $18.33 \%$ \\
\hline & Using digital tools and resources & 0 & 6 & & & 24 \\
\hline & $\begin{array}{l}\text { to plan, manage activities, } \\
\text { develop a solution or complete a } \\
\text { project }\end{array}$ & $0.00 \%$ & $10 \%$ & $16.67 \%$ & $33.33 \%$ & $40 \%$ \\
\hline & Using digital tools and resources & 0 & 2 & & 27 & \\
\hline & $\begin{array}{l}\text { to collect and analyze data, } \\
\text { identify solutions and/or make } \\
\text { informed decisions. }\end{array}$ & $0.00 \%$ & $3.33 \%$ & $21.67 \%$ & $45 \%$ & $26.67 \%$ \\
\hline & Using digital tools and resources & & 6 & & & \\
\hline & $\begin{array}{l}\text { to practice multiple processes and } \\
\text { diverse perspectives to explore } \\
\text { alternative solutions }\end{array}$ & $1.67 \%$ & $10 \%$ & $26.67 \%$ & $\begin{array}{l}38.33 \% \\
)\end{array}$ & $23.33 \%$ \\
\hline \multirow{8}{*}{$\begin{array}{l}\text { V. Digital } \\
\text { Citizenship }\end{array}$} & Using Technology to practice & 0 & & & & \\
\hline & $\begin{array}{l}\text { safe, legal, and responsible use of } \\
\text { information }\end{array}$ & $0.00 \%$ & $21.67 \%$ & $23.33 \%$ & $36.67 \%$ & $18.33 \%$ \\
\hline & Using the appropriate technology & 0 & 0 & 8 & 33 & \\
\hline & $\begin{array}{l}\text { to exhibit a positive attitude to } \\
\text { support collaboration, learning, } \\
\text { and productivity }\end{array}$ & $0.00 \%$ & $0.00 \%$ & $13.33 \%$ & $55 \%$ & $31.67 \%$ \\
\hline & Using technology to demonstrate & 0 & 5 & 3 & 30 & \\
\hline & $\begin{array}{l}\text { personal responsibility for } \\
\text { lifelong learning }\end{array}$ & $0.00 \%$ & $8.33 \%$ & $5 \%$ & $50 \%$ & $36.67 \%$ \\
\hline & Using Technology provides the & 2 & 10 & 10 & 33 & \\
\hline & $\begin{array}{l}\text { appropriate technology to exhibit } \\
\text { leadership for digital citizenship }\end{array}$ & $3.33 \%$ & $16.67 \%$ & $16.67 \%$ & $55 \%$ & $8.33 \%$ \\
\hline \multirow{8}{*}{$\begin{array}{l}\text { VI. Technology } \\
\text { Operations and } \\
\text { Concepts }\end{array}$} & Using Technology helps to & 2 & 8 & 6 & & \\
\hline & $\begin{array}{l}\text { acquire a full understanding of } \\
\text { technology systems }\end{array}$ & $3.33 \%$ & $13.33 \%$ & $10 \%$ & $31.67 \%$ & $41.67 \%$ \\
\hline & Using Technology helps to select & 0 & 1 & 5 & & \\
\hline & $\begin{array}{l}\text { and use applications effectively } \\
\text { and productively }\end{array}$ & $0.00 \%$ & $1.67 \%$ & $8.33 \%$ & $36.67 \%$ & $36.67 \%$ \\
\hline & Using Technology helps easily & 0 & 5 & 15 & 30 & \\
\hline & $\begin{array}{l}\text { providing troubleshoot systems } \\
\text { and applications }\end{array}$ & $0.00 \%$ & $8.33 \%$ & $25 \%$ & $50 \%$ & $16.67 \%$ \\
\hline & Using Technology helps to & & 1 & 7 & & 20 \\
\hline & $\begin{array}{l}\text { transfer current knowledge to } \\
\text { learning of new technologies }\end{array}$ & $0.00 \%$ & $1.67 \%$ & $11.67 \%$ & $53.33 \%$ & $33.33 \%$ \\
\hline
\end{tabular}

Table 1 shows that majority of participants displayed a positive attitude of online distance learning environment as a tool for empowering participants to achieve ISTE Standards within EFL classroom. The findings revealed that most of the participants' responses were Agree and Strongly Agree for all statements of the survey. Each of standards two (communication and collaboration) and five (digital citizenship) got the highest score (86.67\%). Standard one (creativity and innovation got (78.34\%). Standard four (critical thinking, problem-solving and decision-making got (75\%). Standard six 
(technology operations and concepts) got $(73.34 \%)$ while standard three (research and information fluency) got the lowest percentage (58.34\%).

Regarding standard one, statement 2 got the highest positive score because $25(41.67 \%)$ participants agreed that using technology helps to create original works as a means of personal or group expression; as well as $22(36.67 \%)$ strongly agreed to this statement. However, only $10(16.66 \%)$ participants were neutral to this statement and just $3(5 \%)$ participants have disagreed on this. This result indicated that participants showed innovation via using digital technologies to generate ideas, test videos, create articles and solve authentic problems.

For standard two, the highest score went to statement 1.30(50\%) participants agreed and $22(36.67 \%)$ strongly agreed that using digital media to interact, collaborate, and publish with peers, experts, or others employing a variety of digital environments and media. Whereas $5(8.33 \%)$ were confused in their decision so they chose neutral and $3(5 \%)$ of them have disagreed. This result showed that the majority of participants were creative communicators who were able to communicate clearly and creatively through using the appropriate digital media to achieve their goals and create project teams.

Although the participants' responses of standard three were the lowest of all standards, but still $22(36.67 \%)$ participants agreed on statement 4 which deals with applying digital tools allow them process data and report results. In addition to $13(21.67 \%)$ participants who responded by strongly agree. A high number of participants responded negatively; $14(23.33 \%)$ of them disagreed on this statement and $11(18.33 \%)$ of them were disinterested. This result displayed that a large number of participants have become successful constructors who critically use a variety of digital tools and resources to build awareness, employ effective research strategies to find data and enhance their meaningful learning experiences.

For standard four, the best result is again for statement 1. $34(56.67 \%)$ participants agreed, plus $11(18.33 \%)$ participants strongly agreed that using digital tools and resources to let them identify and define authentic problems and significant questions for investigation. Nevertheless, $8(13.33 \%)$ participants were not taking any side, $5(8.33 \%)$ participants disagreed and $2(3.33 \%)$ participants were strongly disagreed on statement one. This result revealed that most participants were computational thinkers, problem solvers and decision-makers who could apply technological methods to identify any problem, break down into parts, analyze data, find solution and take an intelligent decision.

Regarding standard five, statements 2 and 3 were registered the highest scores. The participants' responses were $33(55 \%)$ and $30(50 \%)$ respectively agree; plus $19(31.67 \%)$ and $22(36.67 \%)$ were strongly agree; $8(13.33 \%)$ and $3(5 \%)$ were neutral; nobody disagreed on statement 2 but $5(8.33 \%)$ participants disagreed on statement 3 . These results indicated that the greatest number of participants were aware of the rights, responsibilities and opportunities of living, learning and working in the digital world safely. 
For standard six, the best responses were for statement $2 ; 42(36.67 \%)$ agreed on this statement, $12(36.67 \%)$ strongly agreed, $5(8.33 \%)$ were neutral and only one student 1 $(1.67 \%)$ has disagreed. Few participants chose the option strongly disagreed in all standards. This result exhibited that the majority of the participants were empowered learners to set personal learning goals, improve the learning process, construct networks to customize their learning environment, seek feedback about their practices and identify and explore current technologies to transfer knowledge that support the learning process.

To answer the second question, the respondents were required to complete the second section of the survey which was again a Likert-scale from 0-5 with 0 for totally disagree and 5 for totally agree and then rank the four skills according to the benefits they got from online distance learning developing language proficiency as shown by table 2 below.

Table 2

Descriptive statistics of the participants' perceptions of online distances learning on developing language proficiency

\begin{tabular}{cclllllllll}
\hline Skills & $\mathrm{R}$ & Statement & $\mathrm{SD}$ & $\mathrm{D}$ & $\mathrm{N}$ & $\mathrm{A}$ & $\mathrm{SA}$ & $\mathrm{Mean}$ & $\begin{array}{l}\text { Std. D } \\
\text { Std. } \\
\text { Error } \\
\text { Mean }\end{array}$ \\
\hline Reading & 1 & $\begin{array}{l}\text { Online distance learning } \\
\text { improves my reading } \\
\text { skills effectively }\end{array}$ & 0.00 & 23.34 & 10 & 53.33 & 33.33 & 15.00 & 13.71 & 3.43 \\
\hline Writing & $4 \begin{array}{l}\text { Online distance learning } \\
\text { improves my writing } \\
\text { skills effectively }\end{array}$ & 0.00 & 15 & 26.66 & 41.67 & 16.67 & 15.00 & 7.35 & 1.84 \\
\hline Listening & 2 & $\begin{array}{l}\text { Online distance learning } \\
\text { improves my listening } \\
\text { skills effectively }\end{array}$ & 0.00 & 10 & 11.66 & 46.67 & 31.67 & 15.00 & 10.49 & 2.62 \\
\hline Speaking & 3 & $\begin{array}{l}\text { Online distance learning } \\
\text { improves my speaking } \\
\text { skills effectively }\end{array}$ & 0.00 & 21.67 & 8.33 & 50 & 20 & 12.00 & 10.61 & 2.65 \\
\hline
\end{tabular}

The above Table (2) shows that reading, listening and writing skills got the same and the highest mean score (15.00); whereas speaking skill got the lowest mean score (12.00) which indicated that most participants' responses were positive of online distance learning for enhancing English language learning skills. Table 2 results revealed that a majority of participants $52(86.66 \%)$ ranked reading skill as the first skill they acquire successfully through using online activities. This result presented that digital technology improves participants' critical thinking skills and reading skill effectively through online discussion and their creativity in problem-solving. This is in agreement with (Gómez et al, 2012; Al Zumor et al, 2013) who stated that online learning activities and using technological tools in teaching English environment enrich students English vocabulary and reading skill effectively and enhance their confidence and cooperation for language learning. Moreover, the results are in line with Cakrawati (2017) who indicated the use of online learning platforms in English teaching and learning is effective and satisfactory tools for developing English skills and acquiring new vocabularies. 
In their reaction, the second-best skill is listening skill because 47 (78.34\%) participants agreed and disagreed of its effectiveness in enhancing this skill. This proved that Online distance learning enhanced participants' interaction, communication and collaboration skills through watching authentic videos relating to daily life. The result is in agreement with (Rahmawati, 2016; Hos et al, 2016) in which students considered using multimedia in teaching has many advantages for developing their language skills, particularly listening, and their vocabularies. Besides, they stated that e-learning provided innovative information and rich resources, increased their cooperation to be more active.

According to participants' responses, Table 2 also reveals that seventy percent i.e. about 42 participants considered the speaking skill as the third effective skill which leads to development in their argumentative, communicative and collaborative skills This is in line with (Gómez et al, 2012; Erarslan \& Topkaya,2017; Memić-Fišić \& Bijedić, 2017) who specified that learning via technological tools such as chats, forums, e-mails and videos allow communication and interaction among students, discussing authentic issues and providing feedback about the content of the course. Similarly, students showed a positive attitude about the innovative design and structure of the teaching English language materials provided electronically to them.

As clear from their responses, the participants ranked writing skill as the lowest skill with an agreement from $35(58.34 \%)$ participants. This showed that Online distance learning motivates them to raise their creativity and writing ability through using their language to analyze and paraphrase previous well- written essays. The results also showed enhancement in their writing performance through working in groups to produce a well- written essay. The result is in parallel with (Ahmadi \& Reza, 2018) who believed that online learning environment and the appropriate technology for language learning highly motivates, facilitates and encourages EFL students to learn English language skills effectively. As well, they found that students form a positive attitude of an online learning environment and digital teaching because of its advantages for educators and learners to solve their learning problems in a meaningful way.

Regarding the third question, the participants were asked to write the drawbacks of online distances learning opinions. Data showed that only 46 participants were responding to this question. Data revealed that nearly 18 of them concentrated on the technical and Internet connection problems which prevent them from thorough interaction with their instructor and other students to complete their tasks effectively. This response is inline with (Zamari et al, 2012; Altunay, 2019) study in which the majority of the students have difficulties with technical problems and internet connection preventing them from going online to attend classes and then having difficulties in learning English language skills. Moreover, 6 participants had difficulty with online learning because they were not able to join group discussion and practice speaking skill well. A few students, almost 10, were completely against an online learning environment and considered it as uncomfortable for learning English language skills. They justified this by their disability to finish their tasks and assignments accurately on the limited time including the expenses they need to pay plus their effort; accordingly, they trusted face to face learning more than online distance learning. 
Furthermore, about 12 of them have a lack of technological tools which were necessary to be used for their success. Besides, they were not fully aware of technology and its potential uses essential for online distance learning achievements such as digital media that allow learners to create new forms of interaction, expression, communication, and entertainment in a digital format.

One participant said, "We missed the direct interaction with peers and their virtual help". Another respondent stated that it leads to the absence of real interaction. These findings are in line with Erarslan and Topkaya (2017), that e-learning reduced social interaction.

\section{CONCLUSION}

It can be concluded that online distance learning was an effective instructional method for empowering participants to achieve ISTE Standards within EFL classroom. The result of the research showed that online distance learning in education had positively enhanced digital students' communication and collaboration skills through interacting in a digital environment. It also increases the process of cooperating and publishing with peers to produce group projects effectively and accessing information from numerous resources to be able to analyze and evaluate data, fluently. Besides, it helps improving students critical thinking skills to demonstrate creative thinking, construct knowledge, develop innovative assignments and tasks, use digital tools and explore alternative solutions for authentic problems. Moreover, students revealed positive perceptions of using technology to achieve efficient learning of English language skills via different learning styles through their interaction, attention, attendance and having responsibility for lifelong learning. Further, they showed a wide understanding of technology systems, operations and concepts through selecting appropriate applications and using digital platforms to transfer knowledge into the learning process legally and ethically. Generally, it provides educators and learners with a better alternative for practising flexible and interactive learning.

Despite its plentiful advantages, online distance learning still has some drawbacks such as technical problems, poor or slow internet connections, no physical interactions which may lead to social isolation and students' demotivation to learn well.

Traditionally, online distance learning, as part of the educational world, is found to support non-traditional students including full-time workers, and non-resident students who are unable to attend real classes. Furthermore, as a result of implementing online distance learning, instructors are recommended to be aware of the effectiveness of digital technologies as instructional method to empower their students to achieve ISTE standards within online EFL classroom. Furthermore, it is suggested that instructors have to implement the innovative teaching methods, the latest learning styles and variety of active assessment strategies which may help students to develop language proficiency and enhance their productivity within effective online learning environments. 


\section{REFERENCES}

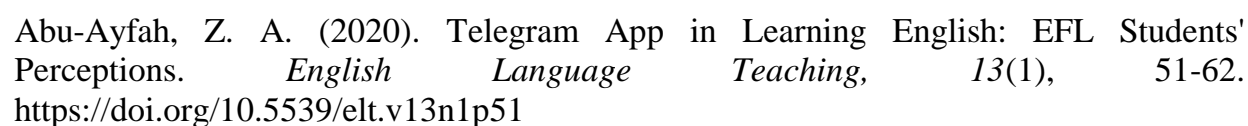

Ahmadi, D., Reza, M. (2018). The use of technology in English language learning: A literature review. International Journal of Research in English Education, 3(2), 115 125. DOI: 10.29252/ijree.3.2.115

Al-Fahad, F. N. (2009). Students' attitudes and perceptions of the effectiveness of mobile learning at King Saud University, Saudi Arabia. Online Submission, 8(2)111119. http://www.tojet.net/articles/v8i2/8210

Altunay, D. (2019). EFL Students' Views on Distance English Language Learning in a Public University in Turkey. Studies in English Language Teaching, 7, 1.121-134. DOI: https://doi.org/10.22158/selt.v7n1p121

Al Zumor, A. W. Q., Al Refaai, I. K., Eddin, E. A. B., \& Al-Rahman, F. H. A. (2013). EFL Students' Perceptions of a Blended Learning Environment: Advantages, Limitations and Suggestions for Improvement. English Language Teaching, 6(10), 95-110. https://eric.ed.gov/?id=EJ1077093

Armstrong, D. (2011). Students' perceptions of online learning and instructional tools: A qualitative study of undergraduate students use of online tools. In E-Learn: World Conference on E-Learning in Corporate, Government, Healthcare, and Higher Education (pp. 1034-1039). Association for the Advancement of Computing in Education (AACE). https://www.learntechlib.org/p/38847/

Basaza, G. N., Milman, N. B., \& Wright, C. R. (2010). The challenges of implementing distance education in Uganda: A case study. The International Review Research in Open and Distributed Learning, 11(2), 85-91. DOI: https://doi.org/10.19173/irrodl.v11i2.833

Bourne, J. R. (1998). Net-learning: Strategies for on-campus and off-campus networkenabled learning. Journal of Asynchronous Learning Networks, 2(2), 70-88. https://nanopdf.com/download/net-learning-online-learning-consortium_pdf

Cakrawati, L. M. (2017). Students' perceptions on the use of online learning platforms in the EFL classroom. English Language Teaching and Technology Journal, 1(1), 22-30. DOI: https://doi.org/10.17509/elt\%20tech.v1i1.9428

Castle, S. R., \& McGuire, C. J. (2010). An analysis of student self-assessment of online, blended, and face-to-face learning environments: Implications for sustainable education delivery. International Education Studies, 3(3), 36-40. http://citeseerx.ist.psu.edu/viewdoc/download?doi=10.1.1.669.8465\&rep=rep1\&type=p df 
Erarslan, A., \& Topkaya, E. Z. (2017). EFL Students Attitudes Of e-Learning And Effect of An Online Course on Students Success in English. The Literacy Trek, 3(2), 80101. https://www.researchgate.net/publication/321626193

Fauzan, A., \& Ngabut, M. N. (2018). EFL students' perception of flipped learning in writing class. Journal on English as a Foreign Language (JEFL), 8(2), 115-129. DOI: 10.23971/jefl.v8i2.792. DOI: 10.23971/jefl.v8i2.792

Feizabadi, N., Aliabadi, K., \& Ahmadabadi, M. N. (2016). The impact of English learning software Moodle. International Journal of Humanities and Cultural Studies (IJHCS) ISSN 2356-5926, I(1), 1427-1437.https://www.ijhcs.com/index.php

Ghanizadeh, A., Razavi, A., \& Jahedizadeh, S. (2015). Technology-Enhanced Language Learning (TELL): A Review of Resources and Upshots. International Letters of Chemistry, Physics and Astronomy, 54, 73.DOI: https://www.scipress.com

Golonka, E. M., Bowles, A. R., Frank, V. M., Richardson, D. L., \& Freynik, S. (2014). Technologies for foreign language learning: a review of technology types and their effectiveness. Computer-assisted language learning, 27(1), 70-105. https://doi.org/10.1080/09588221.2012.700315

Gómez Flórez, É., Pineda, J. E., \& Marín García, N. (2012). EFL students' perceptions about a web-based English reading comprehension course. Profile Issues in TeachersProfessional Development, 14(2), 113-129. http://hdl.handle.net/10495/2918

Hiltz, S. R., \& Turoff, M. (2005). Education goes digital: The evolution of online learning and the revolution in higher education. Communications of the ACM, 48(10), 59-64. https://doi.org/10.1145/1089107.1089139

Himmelsbach, V. (2019). Pros and Cons of Technology in the Classroom in 2019. Retrieved April 4, 2020: https://tophat.com/blog/6-pros-cons-technologyclassroom

Holtman, L. (2009). Using Wikis in the teaching of a short course on history and philosophy of [18] science. International Journal of Instructional Technology and Distance Learning, 6(1), 29-37. https://www.immagic.com/eLibrary/ARCHIVES/

Hos, R., Yagci, H., \& Cinarbas, H. I. (2016). Turkish EFL students' perceptions of blended English courses in a teacher education program. International Journal of Social Sciences and Education Research, 2(3), 774-784. https://dergipark.org.tr/en/pub/ijsser

International Society for Technology in Education. (2011). NETS for coaches. Eugene, OR: Author. Retrieved from www.iste.org/standards/nets-for-coaches.aspx

Kamenetz, A. (2020). 'Panic-gogy': Teaching Online Classes During the Coronavirus Pandemic. Retrieved from: https://www.gpbnews.org/post/panic-gogy-teaching-onlineclasses-during-coronavirus-pandemic 
Kaplan, A. M., \& Haenlein, M. (2016). Higher education and the digital revolution: About MOOCs, SPOCs, social media, and the Cookie Monster. Business Horizons, 59(4), 441-450. https://doi.org/10.1016/j.bushor.2016.03.008

Kaur, H. (2019). "Impact of Digitalization of Higher Education. International Journal of Applied Research, 4, 286-288. https://www.allresearchjournal.com

Keengwe, J., \& Kidd, T. T. (2010). Towards best practices in online learning and teaching in higher education. MERLOT Journal of Online Learning and Teaching, 6(2), 533-541. https://jolt.merlot.org/vol6no2/keengwe_0610.pdf

Lai, C.C \& Kristonis, W. A. 2006. The Advantages and Disadvantages of Computer Technology in Second Language Acquisition. Doctoral Forum National Journal for Publishing and Mentoring Doctoral Students Research, 3(1), 95-110. https://eric.ed.gov/?id=ED492159

McKnight, K., O'Malley, K., Ruzic, R., Horsley, M. K., Franey, J. J., \& Bassett, K. (2016). Teaching in a digital age: How educators use technology to improve student learning. Journal of research on technology in education, 48(3), 194-211. https://doi.org/10.1080/15391523.2016.1175856

Memić-Fišić, I., \& Bijedić, N. (2017). Teaching materials for ESL distance learning. Explorations in English Language and Linguistics, 5(1), 40-54. https://hrcak.srce.hr/216834

Milonm, S. R., \& Hasanand Ipban, H. (2017). Students' perception of technology in learning English as a foreign language: A case study of higher secondary students of Pabna, Bangladesh. IOSR Journal of Humanities and Social Science, 22(6), 47-53. DOI: 10.9790/0837-2206104753 www.iosrjournals.org 47

Moore, J., Dickson-Deane, C., \& Galyen, K. (2011). E-Learning, online learning and distance learning environments: Are they the same? The Internet and Higher Education, 14, 129-135. https://doi.org/10.1016/j.iheduc.2010.10.001

Pozzobon, C. (2008). Podcast and Literature. Entre Lenguas, 13, 111-115. http://www.saber.ula.ve/bitstream/handle/123456789/29564/articulo7.pdf?sequence=2\& isAllowed $=\mathrm{y}$

Rahmawati, F. (2016). E-learning implementation: Its opportunities and drawbacks perceived by EFL students. Journal of Foreign Language, 1(1), 47-53. https://doi.org/10.18196/ftl.111

Shadiev, R., \& Yang, M. (2020). Review of Studies on Technology-Enhanced Language Learning and Teaching. Sustainability, 12(2), 524. https://doi.org/10.3390/su12020524

Shadiev, R., \& Huang, Y. M. (2020). Investigating student attention, meditation, cognitive load, and satisfaction during lectures in a foreign language supported by speech-enabled language translation. Computer Assisted Language Learning, 33(3), 301-326. https://doi.org/10.1080/09588221.2018.1559863 
Shelly, G. B., Gunter, G. A., \& Gunter, R. E. (2013). (5th ed.). Teachers discovering computers: Integrating technology in a connected world. Cengage Learning. https://books.google.ae/books

Smith, R. (2017). ISTE releases new standards for educators to maximize learning for all students using technology. Journal Article). Retrieved from: https://www. iste. org/explore/articleDetail.

Summers, J. J., Waigandt, A., \& Whittaker, T. A. (2005). A comparison of student achievement and satisfaction in an online versus a traditional face-to-face statistics class. Innovative Higher Education, 29(3), 233-250. https://doi.org/10.1007/s10755-005-1938

Suppasetseree, S., \& Dennis, N. (2010). The Use of Moodle for Teaching and Learning English at Tertiary Level in Thailand. International Journal of the Humanities, 8(6), 2946. DOI: 10.18848/1447-9508/CGP/v08i06/42964

Wang, C. H., Shannon, D. M., \& Ross, M. E. (2013). Students' characteristics, selfregulated learning, technology self-efficacy, and course outcomes in online learning. Distance Education, 34(3), 302-323. https://doi.org/10.1080/01587919.2013.835779

Warren, Tom (2020). "Microsoft Teams launches to take on Slack in the workplace". Retrieved April 20, 2020. https://www.theverge.com/2016/11/2/13497992/microsoftteams-slack-competitor-features

Zamari, Z. M., Adnan, A. H. M., Idris, S. L., \& Yusof, J. (2012). Students' perception of using online language learning materials. Procedia-social and behavioural sciences, 67, 611-620. https://doi.org/10.1016/j.sbspro.2012.11.367 